\title{
Factors affecting mechanical ventilation in ICU elderly patients
}

\author{
E Pappa*, H Pavlou, M Eforakopoulou \\ From ESICM LIVES 2015 \\ Berlin, Germany. 3-7 October 2015
}

\section{Introduction}

In recent years the rate of elderly patients being hospitalized in ICU and requiring respiratory support has increased. The rapid weaning from mechanical ventilation is often difficult in these patients.

\section{Objectives}

The aim of this study is to search for the factors that influence the duration of the elderly patients' mechanical ventilation.

\section{Methods}

We studied retrospectively 74 patients $>65$ years old, who have been hospitalized in ICU and underwent mechanical ventilation. The patients, depending on the duration of the mechanical respiratory support (MRS), have been divided into two groups. Group A: MRS $<10$ days and Group B: MRS $>10$ days. We have recorded the age, the gender, the cause of admission in ICU, the comorbidities (Charlson comorbidity index), the duration of hospitalization, the complications and the outcome. For the statistics analysis we have used $t$ - student and chi-square tests.

\section{Results}

We studied 43 men and 31 women with average age 79 \pm 6.4 years old. The cause of admission in ICU has been trauma (26\%), surgical reasons (18\%) and pathological reasons (57\%) and it has not been related to the length of mechanical ventilation. The increased comorbidity (Charlson comorbidity index) and the ICU complications (pneumonia, sepsis-MODS) have significantly increased the duration of mechanical ventilation ( $\mathrm{p}<$ 0.01 ). The length of hospital stay and mortality were

KAT General Hospital, ICU, Athens, Greece considerably greater among patients in Group B $(\mathrm{p}=$ 0.003 and $\mathrm{p}=0.0006$ respectively).

\section{Conclusions}

The comorbidities and the complications during ICU hospitalization increase the duration of mechanical respiratory support in elderly patients. The length of hospital stay and the mortality are increased in these patients.

Published: 1 October 2015

\section{References}

1. Scheinhorn DJ, et al: Liberation from prolonged mechanical ventilation. Crit Care Clin 2002, 18(3):569-95.

2. Benhamou $D$, et al: Mechanical ventilation in elderly patients. Monaldi Arch Chest Dis. 1998, 53(5):547-51.

doi:10.1186/2197-425X-3-S1-A660

Cite this article as: Pappa et al:: Factors affecting mechanical ventilation in ICU elderly patients. Intensive Care Medicine Experimental 2015 3(Suppl 1):A660.

\section{SpringerOpen ${ }^{\circ}$}

(c) 2015 Pappa et al.; This is an Open Access article distributed under the terms of the Creative Commons Attribution License (http:// creativecommons.org/licenses/by/4.0), which permits unrestricted use, distribution, and reproduction in any medium, provided the original work is properly cited.
Submit your manuscript to a SpringerOpen ${ }^{\circ}$ journal and benefit from:

- Convenient online submission

- Rigorous peer review

- Immediate publication on acceptance

- Open access: articles freely available online

- High visibility within the field

Retaining the copyright to your article

Submit your next manuscript at $>$ springeropen.com 